\title{
Administrasi Keuangan untuk Baitul Mal wat Tamwil (BMT)
}

\author{
Irda Rosita \\ Firman Surya \\ Eliyanora
}

Politeknik Negeri Padang

\begin{abstract}
Abstrak
Perkembangan perbankan syariah di Indonesia ditandai dengan berdirinya Bank Muamalat Indonesia (BMI). Akan tetapi karena permasalahan birokrasi dan terikat dengan undang-undang perbankan yang berlaku, BMltidak dapat mencapai lapisan paling bawah masyarakat Indonesia, sehingga dibentuklah lembaga keuangan alternatif yaitu Baitul Mal wa Tamwil (BMT) yang tidak hanya berorientasi aspek bisnis tetapai juga aspek sosial. BMT Mesjid Raya Koto Baru dan Mesjid Al Manar merupakan lembaga keuangan ekonomi mikro yang berbasis di Solok, Sumatera Barat. Kedua BMT ini telah memberikan kontribusi dalam meningkatkan perekonomian masyarakat kecil sekitar BMT tersebut, melalui penyaluran pinjaman lunak. Semua dana BMT berasal dari sumbangan donatur dalam jumlah yang masih sangat terbatas. Peluang penambahan sumber pendanaan BMT masih besar melalui hibah pemerintah dan tambahan sumbangan donatur. Namun, karena keterbatasan BMT dalam memberikan informasi keuangan sebagai pertanggungjawaban menyebabkan BMT belum maksimal memanfaatkan peluang yang ada. Untuk itu perlu dirancangkan aplikasi sistem informasi akuntansi yang cocok untuk BMT. Perancangan dilakukan dengan 3 tahapan: analisis sistem, perancangan sistem dan implementasi sistem. Hasil dari implementasi sistem ini adalah BMT dapat melakukan administrasi keuangannya secara cepat, tepat dan lengkap.
\end{abstract}

Keyword: BMT, kendala BMT, aplikasi sistem informasi akuntansi berbasis web

\begin{abstract}
Pendahuluan
Sejarah Baitul Mal wat Tamwil (BMT)

Baitul mal berasal dari Bahasa Arab yang dapat didefinisikan sebagai suatu lembaga atau pihak (al jihat) yang mempunyai tugas khusus menangani segala harta umat, baik berupa pendapatan maupun pengeluaran negara (Dahlan, 1997). Baitul mal ini sudah ada sejak zaman Rasulullah SAW. Pada waktu itu, baitul mal bukan hanya berfungsi seperti BAZIS pada zaman sekarang (mengumpulkan dana yang akan digunakan untuk kemaslahatan umat) akan tetapi juga berfungsi sebagai lembaga pengelola keuangan negara. Baitul mal terus berkembang pada masa Khulafaur Rasyidin. Akan tetapi, pada masa penjajahan yang terjadi di negara-negara Islam, telah membawa perubahan dalam sistem pemerintahan, politik dan terutama dalam bidang ekonomi, sehingga masa itu
\end{abstract}

baitul mal telah hilang dalam khasanah kenegaraan.

Pengangguran, inflasi serta terpisahnya agama dan ekonomi serta politik merupakan permasalah lanjutan yang dihadapi pasca penjajahan negara Islam yang pada akhirnya menghambat pembangunan ekonomi di negara Islam meskipun mereka telah merdeka. Hal ini menimbulkan pemikiran di kalangan negara Islam, bahwa perlu dicari terobosan baru sebagai solusi untuk mengatasi masalah ekonomi. Gerakan lembaga keuangan yang bebas riba dengan sistem modern didirikan pada tahun 1969 oleh Abdul Hamid An Maghar di desa Mith Gramer, tepi sungai Nil di Mesir. Meskipun akhirnya ditutup karena masalah manajemen, akan tetapi kelahiran Bank ini telah mengilhami diadakannya Konferensi Ekonomi Islam yang pertama pada tahun 1975 di Mekah. Dua tahun kemudianlahirlah Islamic Development 
Bank (IDB). IDB merupakan cikal bakal berdirinya perbankan syariah di negara-negara Islam.

Di Indonesia sendiri, sejarah bank syariah dimulai di tahun 1991 ketika berdiri pertama kali Bank Muamalat Indonesia sebagai bank syariah. Bank ini berdiri atas prakarsa Majelis Ulama Indonesia (MUI). Perkembangan selanjutnya adalah berdiri BPR syariah. Akan tetapi, karena masalah birokrasi dan undang-undang perbankan yang ada, maka kedua bentuk lembaga perbankan ini tidak menyentuh kalangan bawah. Oleh karena itu, dibentuklah lembaga keuangan alternatif yang tidak hanya berorientasi bisnis tetapi juga sosial. Lembaga yang terlahir dari kesadaran umat dan ditakdirkan untuk menolong kaum mayoritas, yakni pengusaha kecil/mikro. Lembaga yang tidak terjebak pada permainan bisnis untuk keuntungan pribadi, tetapi membangun kebersamaan untuk mencapai kemakmuran bersama. Lembaga yang tidak terjebak pada pikiran pragmatis tetapi memiliki konsep idealis yang istiqomah. Lembaga tersebut adalah Baitul Māl Wa Tamwil (BMT).

Saat ini BMT mengalami perkembangan cukup signifikan dalam beberapa tahun terakhir. Selain itu, kehadiran BMT mampu menjadi sarana dalam menyalurkan dana untuk usaha bisnis kecil dengan mudah dan bersih, karena didasarkan pada kemudahan dan bebas riba/bunga, memperbaiki/meningkatkan taraf hidup masyarakat bawah. BMT juga menjadi lembaga keuangan alternatif yang mudah diakses oleh masyarakat bawah dan bebas riba/bunga dan lembaga untuk memberdayakan ekonomi ummat, mengentaskan kemiskinan, meningkatkan produktivitas.

\section{Permasalahan yang Dihadapi BMT \\ Walaupun BMT memiliki peran yang cukup besar, akan tetapi tetap saja akan ada permasalahan yang dihadapi oleh BMT. Diantaranya adalah akumulasi dana yang dibutuhkan masyarakat belum bisa dipenuhi oleh BMT, seperti yang dialami oleh BMT Mesjid Raya Koto Baru, Kab. Solok dan BMT Mesjid Al Manar, Kota Solok. Hal ini dikarenakan pengurus BMT belum bisa}

menyediakan informasi akuntabilitas pengelolaan keuangan secara cepat dan tepat kepada para donatur, karena saat ini kedua BMT masih mengelola keuangannya secara manual. Oleh karena itu, melalui artikel ini, Penulis menyajikan bagaimana solusi yang ditawarkan kepada kedua BMT untuk menghadapi permasalahannya.

\section{BMT Mesjid Raya Koto Baru}

BMT Masjid Raya Koto Baru Kec. Kubung Kab. Solok untuk selanjutnya disebut BMT Masjid Raya Koto Baru telah berdiri sejak bulan Februari 2004 atas prakarsa beberapa tokoh masyarakat yang ada di kampung dan di rantau, diantaranya adalah Bapak $\mathrm{H}$. Bukhari Alma sebagai perwakilan warga yang ada di rantau dan Bapak Zul Elfian sebagai perwakilan warga yang ada di kampung. Pada saat berdiri modal yang ada hanya sebesar Rp 5.000.000,-. Dana tersebut dipinjamkan kepada para nasabah anggota jamaah subuh sebesar Rp 300.000,- per orang tanpa bunga. Tujuan pendirian BMT ini adalah:

- Agar nasabah rajin sholat berjamaah, terutama sholat subuh di masjid

- Agar rajin, disiplin dan jujur membayar utang

- Agar orang yang mampu bersedia mengeluarkan zakat, infaq, sedekah atau sumbangan melalui BMT

- Agar pengurus BMT dapat dipercaya dan mampu mendidik nasabah menjadi orang yang jujur

- Membantu atau tolong menolong sesama dalam kebaikan, wataawanu alal birri wattaqwa

- Meningkatkan ekonomi msyarakat kecil dalam nagari

- Memakmurkan (immaratul) masjid

Seiring dengan berjalannya waktu dan adanya tambahan modal BMT, saat ini dana yang dapat dipinjamkan sudah meningkat menjadi Rp 500.000,- per nasabah dan dibayarkan per minggu untuk 20 kali angsuran.

Kegiatan BMT Masjid Raya Koto Baru ini merupakan kegiatan sosial yang dilaksakan oleh pengurus harian. Dengan 
semakin banyaknya jumlah nasabah peminjam, pengurus harian akhirnya menunjuk 3 orang pelaksana harian yang bertanggung jawab dalam penerimaan serta penagihan nasabah-nasabah yang terlambat membayar angsuran. Kegiatan BMT hanya dilaksanakan 2 kali seminggu yaitu: setiap hari Kamis malam dan Minggu malam untuk pelaksanaan penerimaan angsuran pinjaman dan pemberian pinjaman baru kepada nasabah. Dana yang dipinjamkan tersebut tidak dipungut bunga, namun hanya dikenakan provisi sebesar 3\% setiap pinjaman. Provisi yang dipungut digunakan untuk operasional BMT serta bantuan transportasi kepada 3 orang pelaksana harian yang melakukan pemungutan angsuran setiap minggunya.

Menurut penuturan nasabah, pinjaman dari BMT Masjid Raya Koto Baru sangat besar manfaatnya karena nasabah dengan mudah mendapatkan pinjaman, tidak berbelit-belit dan tidak ada bunga. Selama ini mereka sering terjerembab berutang kepada rentenir yang berkeliaran di kampung. Istilah mereka "pinjam 4 bayar 6" sehingga pada akhirnya mereka dililit utang. Keberadaan BMT dianggap sebagai penyelamat kehidupan dan usaha/ bisnis mereka walaupun kecil-kecilan.

\section{BMT Mesjid Raya Al Manar}

BMT Masjid Al-Manar didirikan pada bulan Desember 2004. Cikal bakal pendirian BMT ini merupakan ide dan prakarsa dari Bapak Ch. Latief, SH, M.Si Dt .Bandaro bersama beberapa perantau dan beberapa warga yang berada di kampung. BMT Masjid Al-Manar bukan hanya bertujuan untuk meningkatkan ekonomi masyarakat sekitar, tetapi juga bertujuan untuk meningkatkan Keimanan dan Ketaqwaan kepada Allah SWT.

Secara spesifik, BMT ini bertujuan antara lain:

- Meramaikan sholat berjamaah di Masjid Al-Manar

- Mengatasi kesulitan modal usaha kecil

- Mengatasi kesulitan dana insidentil bagi masyarakat kurang mampu

- Menerima dan menyalurkan zakat bagi yang berhak

- Menunjang kegiatan Usaha Ekonomi Produktif (UPE) masyarakat sekitar.
Visi BMT Mesjid Al Manar adalah "Menjadikan BMT sebagai lembaga keuangan syariah terpercaya, dapat menjadi contoh dalam membangkitkan ekonomi jemaah Masjid Al-Manar melalui pinjaman tanpa bunga dengan modal yang dihimpun melalui donatur/zakat/infaq/shadaqah". Sedangkan misinya adalah sebagai berikut:

- Menggali sumber potensi zakat, infaq dan shadaqah (ZIS) serta sumber-sumber lainnya

- Menggunakan ZIS yang terkumpul untuk keperluan modal pinjaman usaha kecil, memberikan pinjaman darurat dan memberikan ZIS kepada para mustahiknya.

- Membuka usaha-usaha lainnya sesuai kemampuan

- Memakmurkan masjid dengan cara mengajak para jamaah untuk menjadi donator, meramaikan masjid dengan melaksanakan sholat lima waktu secara berjamaah.

- Meningkatkan taraf hidup masyarakat dengan jalan memupuk permodalan usaha kecil dan menengah.

Pada awal berdirinya, BMT Masjid AlManar mempunyai Modal Dasar sebesar Rp 18.500.000,- yang berasal dari para donatur/ dermawan yang ada di rantau dan di kampung. Setelah hampir 2 tahun didirikan, BMT ini telah mampu menghimpun dana sebesar $\mathrm{Rp}$ 42.500.000 dan selama 2 periode tersebut telah melayani masyarakat ekonomi lemah sebanyak 173 orang nasabah. Kelompok terbesar peminjam adalah bidang usaha yanga jualan kecil-kecilan (dagang lontong, makanan ringan dan nasi). Waktu dan tempat pelayanan penyaluran pinjaman dilaksanakan setiap hari Kamis setelah sholat Isya. Setiap transaksi tidak dipungut bunga hanya dikenakan biaya pungut sebesar $2,5 \%$ sebagai biaya administrasi. Saat ini pinjaman yang diberikan kepada nasabah adalah $\mathrm{Rp} 500.000$ yang dicicil per minggu selama 20 minggu.

\section{Permasalahan BMT Mesjid Raya Koto Baru dan Mesjid Al Manar \\ Keberadaan BMT Mesjid Raya Koto} Baru sangat diharapkan oleh masyarakat terutama yang berada di 3 jorong, yaitu: 
Jorong Lubuk Agung, Bawah Duku dan Simpang. Begitu pula dengan BMT Mesjid AlManar, keberadaannya sangat diharapkan oleh masyarakat kelurahan Nan Balimo kec. Tanjung Harapan Solok. Warga yang membutuhkan pinjaman dari BMT meningkat cukup pesat sehingga BMT harus aktif mencari sumber dana dari donatur lain karena dana yang ada saat ini tidak cukup untuk menampung banyaknya permohonan pinjaman nasabah.

Sebenarnya peluang untuk mendapatkan tambahan dana masih terbuka cukup luas karena perhatian dari perantau dan donatur di kampung untuk meningkatkan kesejahteraan dan perekonomian masyarakat cukup tinggi. Namun permasalahannya, pengurus belum mampu menyajikan informasi keuangan yang dapat diandalkan karena sistem keuangan pada kedua BMT saat ini masih dilakukan secara manual dan sangat sederhana. Setiap penerimaan dana dari angsuran pinjaman serta pengeluaran dana untuk penyaluran pinjaman atau operasional hanya dicatat kedalam buku catatan kas. Dengan perkembangan teknologi yang ada saat ini memungkinkan kedua BMT dapat mengelola sistem keuangannya dengan lebih baik sehingga pengurus dapat menyajikan informasi keuangan yang dikelola dengan lebih professional, dapat dipercaya dan dipertanggungjawabkan. Hal ini diyakini akan memberikan dampak atas tambahan dana dari donatur yang ada di rantau maupun di kampung.

\section{Metodologi}

Metodologi penelitian yang dilaksanakan adalah action research dengan studi kasus pada organisasi BMT yang terdapat di kota Solok. Data dikumpulkan dengan melakukan observasi dan wawancara dengan pengurus BMT untuk mengetahui sejarah pendirian BMT, operasional dan kendala-kendala yang dihadapi beserta tawaran solusi yang bisa diberikan. Setelah mitra setuju dengan solusi yang diberikan, maka langkah selanjutnya adalah merancang sistem informasi melalui media dokumentasi perancangan berupa rancangan DFD, prosedur dan rancangan ralalsional database. Setelah seluruh rancangan tersebut dibuat dilanjutkan dengan merancang sistem secara fisik berupa program aplikasi.

\section{Hasil dan Pembahasan \\ Solusi Permasalahan BMT Mesjid Raya Koto Baru dan Mesjid Al Manar}

Dengan semakin bertambahnya nasabah pinjaman BMT, tentunya akan meningkatkan beban kerja administrasi pengurus pinjaman. Pengurus pinjaman dituntut untuk dapat melaksanakan tugas administrasi dengan cepat, akurat dan efisien. Aplikasi administrasi pinjaman BMT dirancang bertujuan untuk memudahkan pelaksanaan tugas-tugas administrasi pemberian pinjaman, penagihan, pencatatan kas dan pelaporan. Permasalahan yang dihadapi mitra dapat diatasi dengan cara pembuatan administrasi keuangan berbasis web. Dengan diterapkannya aplikasi ini, diharapkan dapat mengurangi pekerjaanpekerjaan manual yang dilaksanakan oleh pengurus terutama pada proses input dan pelaporan. Aplikasi ini diharapkan dapat mengolah data dan menghasilkan informasi dengan cepat dan akurat.

Untuk merancang sistem informasi akuntansi, dilakukan melalui tahapan-tahapan berikut ini (Mulyadi, 2010):

1. Analisis sistem

Analisis sistem dilakukan untuk mengetahui sistem akuntansi yang sedang dijalankan oleh mitra saat ini, kelemahan/kendala yang dihadapi serta sistem informasi akuntansi yang diinginkan oleh mitra

2. Perancangan Sistem

Berdasarkan analisis sistem yang telah dilakukan, kegiatan selanjutnya adalah merancang sistem yang sesuai dengan kondisi dan keinginan mitra

3. Implementasi Sistem

Sistem informasi akuntansi yang telah dirancang diserahkan ke mitra untuk dilakukan uji coba.

\section{Analisis Sistem}

Dalam tahap pertama, perlu dilaksanakan observasi dan survey ke BMT untuk mendapatkan data-data yang dibutuhkan untuk merancang Sistem Informasi Akuntansi 
mitra. Data yang diperoleh tersebut berupa laporan dan catatan keuangan BMT dalam memproses simpanan dan pinjaman anggota serta operasional lainnya. Selain itu,data lain yang berhasil dikumpulkan adalah tentang prosedur simpanan dan pinjaman pada BMT. Data yang sudah didapatkan diolah dan menjadi dasar dalam menyusun aplikasi sistem informasi akuntansi yang tepat bagi BMT ini. Berdasarkan hasil observasi dan wawancara yang dilakukan dengan mitra, penulis dapat memahami kebutuhankebutuhan sistem informasi mitra. Kebutuhan utama sistem informasi adalah peralihan proses penyimpanan dan pengolahan data dari metode manual menjadi metode berbasis komputer.

Sistem informasi berbasis komputer yang dibutuhkan oleh mitra tersebut adalah yang dapat membantu proses pengelolaan data nasabah, pengelolaan pengajuan pinjaman, pengelolaan penerimaan cicilan dan pengolahan data menjadi laporan keuangan. Beberapa kebutuhan khusus mitra yang harus dipenuhi oleh sistem informasi yang baru adalah kemampuan aplikasi untuk menyajikan informasi daftar nasabah atau pinjaman yang akan jatuh tempo dalam periode penagihan setiap minggunya, informasi yang dibutuhkan adalah nilai cicilan pokok setiap nasabah, nilai denda dan akumulasi denda dan nilai sisa pinjaman. Laporan tersebut akan dicetak setiap periode penagihan dan digunakan untuk membantu petugas administrasi kredit menagih kepada masing-masing nasabah.

Laporan keuangan yang dihasilkan adalah laporan posisi keuangan atau neraca dan laporan laba rugi yang menggambarkan aktivitas operasional. Laporan-laporan tersebut dihasilkan dengan memasukkan periode waktu data transaksi.

\section{Perancangan Sistem}

Selanjutnya, untuk tahapan perancangan dan pengembangan aplikasi sistem informasi akuntansi dapat dijabarkan sebagai berikut:

Berdasarkan hasil observasi yang telah dilakukan terhadap aspek bisnis dan kegiatan BMT, dapat digambarkan context diagram dan data flow diagram level 0 dari sistem informasi administrasi pinjaman pada
BMT yang akan dikembangkan, lihat lampiran 1 dan 2.

Program aplikasi dikembangkan dengan script HTML dan PHP. Untuk mendasain antarmuka pemakai digunakan software dreamweaver. Untuk pengelolaan database aplikasi digunakan MySql yang diinstallkan dengan paket XAMPP, didalam paket tersebut juga terinstall Apache web server yang akan melayani request halaman web aplikasi dari klien.

Aplikasi dirancang berdasarkan proses bisnis yang terjadi pada mitra. Proses bisnis yang diidentifikasi berupa pengelolaan data utama nasabah, pencairan pinjaman, penagihan cicilan pinjaman dan proses pelaporan.

Proses pengelolaan data utama nasabah berfungsi untuk menambah dan melakukan update data nasabah yang sudah ada seperti perubahan alamat, nomor identitas dan lain sebagainya. Setiap nasabah diidentifikasi dengan nomor kode nasabah dan dilengkapi dengan data dokumen identitas seperti KTP dan SIM. Pengelolaan data nasabah berguna untuk memastikan bahwa setiap nasabah terdaftar dengan data yang valid dan tidak ada nasabah yang sama memiliki data ganda.

Proses pencairan pinjaman dimulai dengan menerima permohonan pinjaman dari nasabah yang telah terdaftar dalam data nasabah, jika nasabah tersebut belum terdaftar, petugas terlebih dahulu harus mendaftarkan nasabah tersebut melalui fungsi pengelolaan data nasabah. Setelah menerima permohonan pinjaman, petugas akan menginput kode nasabah ke fungsi pencairan pinjaman, program aplikasi akan memeriksa data pinjaman yang masih belum lunas dengan kode nasabah tersebut, jika nasabah yang bersangkutan masih memiliki status pinjaman yang belum lunas maka transaksi pencairan pinjaman tidak bisa dilanjutkan. Proses pencairan dilanjutkan dengan menginput data pinjaman yang disetujui untuk nasabah tersebut dengan menginput nilai nominal pinjaman, jumlah periode cicilan dan biaya administrasi yang dipotong saat pencairan. Pada saat pencairan pinjaman yang disetujui, program aplikasi akan secara 
otomatis mencatat jurnal kedalam database. Jurnal yang dibuat akan mengkredit kas keluar sejumlah nilai nominal pinjaman dikurangi dengan biaya administrasi yang dipotong, mendebit piutang pinjaman sejumlah nilai nominal dan mengkredit pendapatan administrasi senilai biaya administrasi yang dipotong.

Proses pembayaran cicilan dimulai dengan dicetaknya informasi daftar tagihan cicilan setiap pinjaman nasabah untuk periode penagihan yang dilakukan setiap minggu. Laporan ini dicetak untuk memudahkan petugas menagih dan menerima pembayaran tagihan dari nasabah yang bersangkutan. Proses penerimaan tagihan ini dilakukan secara manual untuk mempersingkat waktu dan mengurangi terjadinya kesalahan jika pada saat yang sama petugas juga mengoperasikan perangkat komputer untuk menginput data. Didalam laporan penagihan tersebut dilengkapi dengan kolom pembayaran nominal cicilan dan denda untuk masingmasing nasabah. Setelah proses penagihan selesai, petugas akan menginputkan data transaksi penagihan tersebut kedalam program aplikasi dengan cara mengklik kode pinjaman nasabah yang bersangkutan dan memasukkan data pembayaran nominal dan denda yang dibayarkan oleh nasabah. Pada saat data transaksi penagihan cicilan pinjaman diinputkan oleh petugas, program aplikasi akan membuat jurnal transaksi secara otomatis. Jurnal transaksi yang dibuatkan oleh program aplikasi kedalam database adalah mendebit kas sejumlah uang yang diterima dari pembayaran cicilan dan denda, mengkreditkan piutang pinjaman senilai pokok cicilan yang dibayarkan dan mengkreditkan pendapatan denda senilai denda yang dibayarkan oleh nasabah.

Proses input transaksi selain pencairan dan penerimaan cicilan dilakukan pada form jurnal umum. Form ini diisi dengan memasukkan nomor bukti jurnal, tanggal dan keterangan mengenai transaksi yang diinputkan ayat jurnalya, selanjutnya diinputkan ayat jurnal debit dan kredit yang sesuai beserta nominal transaksi. Aplikasi
Aplikasi sistem informasi administrasi pinjaman dibangun dalam arsitektur PHP dan MySQL sebagai database server. Aplikasi ini dapat dijalankan secara local maupun dalam jaringan dengan menggunakan software aplikasi web browser. Mitra pengabdian akan diberikan hardware berupa PC maupun Notebook dengan spesifikasi prosesor Intel Core i3 yang memadai untuk menjalankan software aplikasi ini. Untuk keperluan administrasi dan pencetakan informasi mitra pengabdian juga diberikan 1 unit printer multi function dengan biaya operasional yang relatif murah.

PHP merupakan singkatan rekursif dari Hypertext Preprocessor. Bahasa PHP diciptakan oleh Rasmus Lerdorf pada tahun 1994 sebagai bahasa skrip yang dapat digabungkan kedalam bahasa HTML. Lisensi PHP gratis sehingga dapat digunakan secara bebas untuk mengembangkan software aplikasi. Dengan menggunakan PHP, developer aplikasi menjadi lebih mudah untuk mengembangkan aplikasi yang berhubungan dengan server database karena kemampuan PHP untuk menangani koneksi dan menyampaikan query ke server database.

Apache merupakan software aplikasi web server yang dipaketkan ketika komputer diinstal XAMPP. web server berfungsi melayani permintaan web browser atas halaman web tertentu. Apache web server mendukung penggunaan bahasa PHP.

MySQL merupakan software aplikasi server manajemen database yang handal dan dapat digunakan secara gratis. Sebuah database server database berfungsi untuk melayani proses pembuatan database, penyimpanan data dan permintaan data melalui bahasa query (SQL).

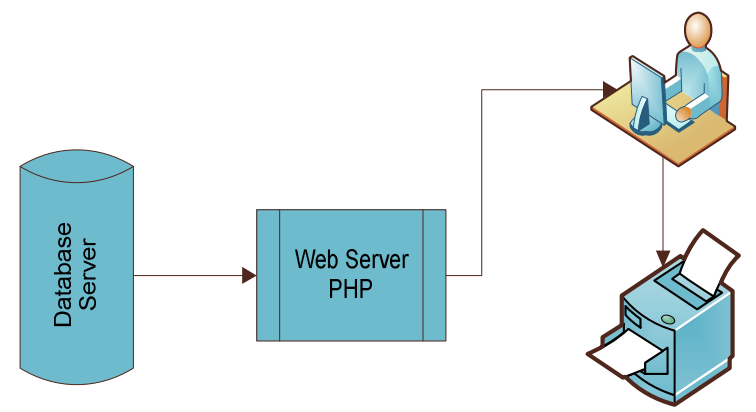

\section{Application Architecture Design}




\section{Gambar 1. Application Architecture Design}

Untuk dapat menunjang aplikasi sistem informasi ini dapat berjalan dengan baik, maka diperlukan spesifikasi peralatan (hardware) sebagai berikut:

\begin{tabular}{|l|l|}
\hline \multicolumn{1}{|c|}{ Hardware } & \multicolumn{1}{c|}{ Spesifikasi } \\
\hline Built-up PC & Intel Core i3 $4^{\text {th }}$ - \\
& Generation \\
& 2GB DDR3 \\
& 500GB Harddisk \\
& 10/100/1000 Mbps \\
& Ethernet \\
& 650VA Uninteruptible \\
& Power Supply \\
\hline Notebook & Intel Core i3 4 \\
& Generation \\
& 2GB DDR3 \\
& 500GB Harddisk \\
& 10/100/1000 Mbps \\
& Ethernet \\
& WLAN/ Bluetooth \\
\hline Printer & HP Deskjet 1515 \\
& Multifunction Inkjet \\
& Printer \\
\hline
\end{tabular}

Rancangan input aplikasi didesain dengan sebaik mungkin untuk memudahkan user menginput data. Aplikasi yang dirancang tersebut dapat dijalankan pada aplikasi web browser seperti mozilla firefox, internet explorer dan google chrome. Pemilihan basis aplikasi web didasarkan atas kemudahan akses terhadap aplikasi, kemudahan melakukan instalasi klien dan kemudahan update atau revisi aplikasi pada sisi server.

Rancangan output aplikasi dibuat untuk mampu menghasilkan laporan-laporan dalam format PDF dan mampu untuk dicetak secara langsung ke printer. Penyajian laporan dalam bentuk PDF sangat berguna karena pengguna dapat memeriksa terlebih dahulu laporan yang yang dihasilkan oleh aplikasi sebelum dicetak ke printer.

\section{Implementasi Sistem}

Metode implementasi yang digunakan adalah metode paralel, dimana mitra masih menggunakan prosedur yang selama ini dipakai sambil menggunakan aplikasi yang baru. Pemilihan metode ini untuk menghindari risiko kegagalan sistem baru yang setiap saat bisa terjadi sehingga tidak mengganggu operasional sehari-hari. Aplikasi sistem informasi telah digunakan oleh mitra, terutama aplikasi untuk administrasi peminjaman. Mitra telah menginputkan data nasabah/peminjam dan saldo pinjaman masing-masing nasabah. Mitra sudah bisa mendapatkan informasi mengenai transaksi pencairan, penerimaan cicilan, penerimaan denda dan penerimaan pendapatan administrasi kredit. Pada lokasi usaha mitra dipasangkan peralatan dan aplikasi yang telah diusulkan dan dipastikan dapat beroperasi dengan baik.

Kegiatan implementasi ini juga dilengkapi dengan penyusunan prosedur operasi standar kegiatan utama BMT dan penyusunan buku manual aplikasi sistem informasi akuntansi pembiayaan BMT.

\section{Evaluasi dan Pendampingan}

Setelah proses implementasi selesai, tim selalu berkomunikasi dan memantau penggunaan aplikasi dan peralatan yang telah diberikan untuk melihat permasalahan yang mungkin terjadinya dan mencarikan solusi yang tepat untuk mengatasi permasalahan tersebut. Apabila mitra sudah tidak mengalami kendala dalam mengoperasikan sistem yang baru dan dirasa sudah bisa untuk mandiri, maka proses implementasi dan evaluasi telah selesai.

\section{Kesimpulan dan saran}

Dengan merancang dan mengimplementasikan sistem informasi administrasi keuangan berbasis web, BMT dapat melaksanakan operasional dengan lebih baik. Pengendalian administrasi pinjaman menjadi lebih baik karena kemungkinan pengajuan pinjaman baru oleh nasabah yang belum melunasi pinjaman dapat dicegah. Petugas administrasi dapat dengan mudah menyelesaikan administrasi pembayaran cicilan setelah menerima seluruh transaksi pembayaran dengan mengisi lembar laporan penagihan pinjaman. Dengan semakin baiknya kualitas operasional administrasi pinjaman 
Administrasi Keuangan untuk Baitul Mal Wat Tamwil

BMT, diharapkan pelayanan semakin baik dan dapat membantu memperlancar roda perekonomian masyarakat kecil.

\section{Daftar Referensi}

Dahlan, Abdul Aziz. et.al. 1999. Ensiklopedi Hukum Islam. Cetakan II. Jakarta : PT Ichtiar Baru van Hoeve

Mulyadi. 2010. Sistem Akuntansi, Edisi 5. Salemba Empat, Jakarta.

8 Jurnal Akuntansi \& Manajemen Vol 10 No.1Juni 2015. ISSN 1858-3687 hal 1-12 
Lampiran 1

Context Diagram

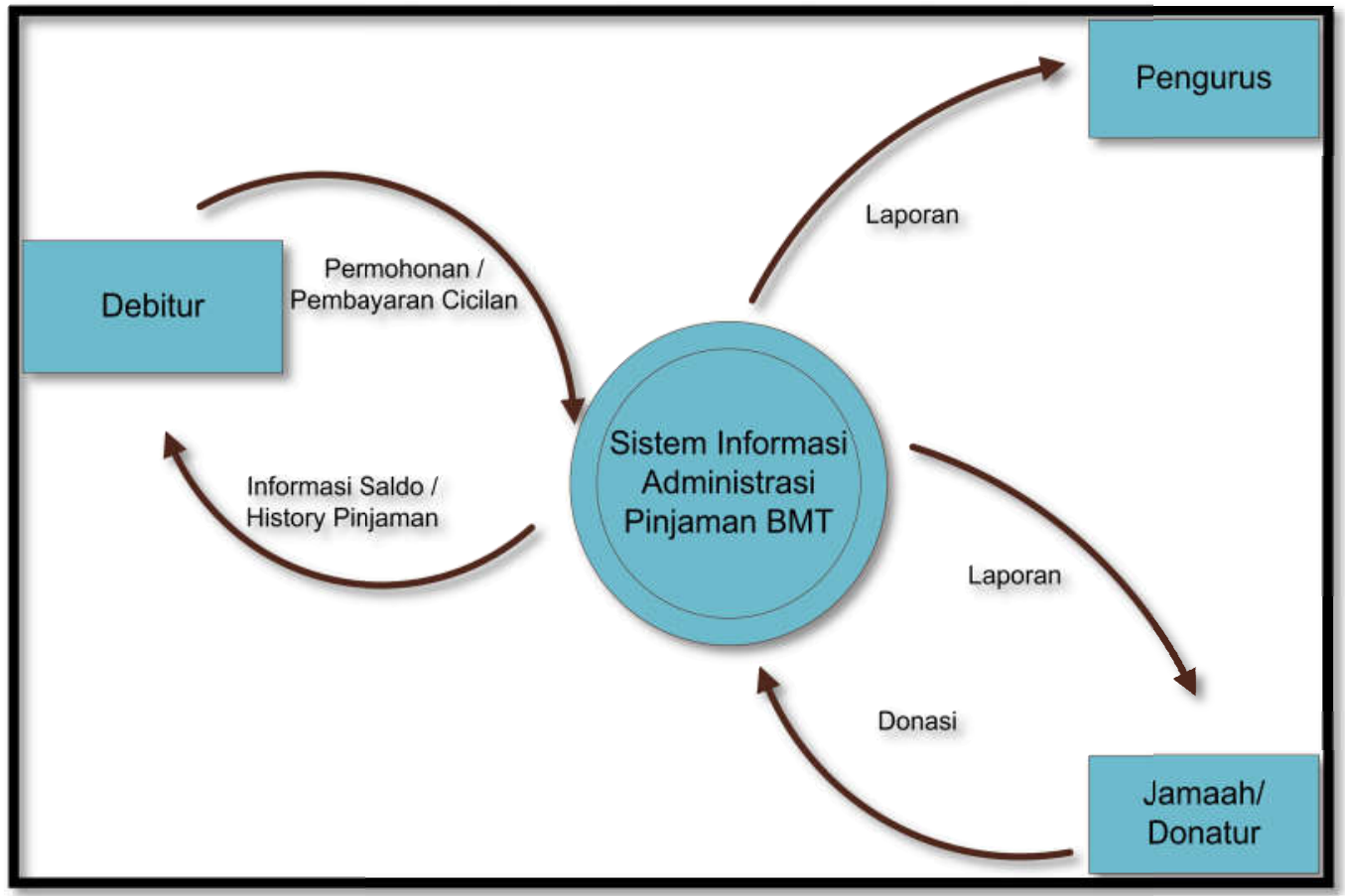

Jurnal Akuntansi \& Manajemen Vol 10 No.1Juni 2015. ISSN 1858-3687 hal 1-12 9 
Lampiran 2

Data Flow Diagram Level - 0

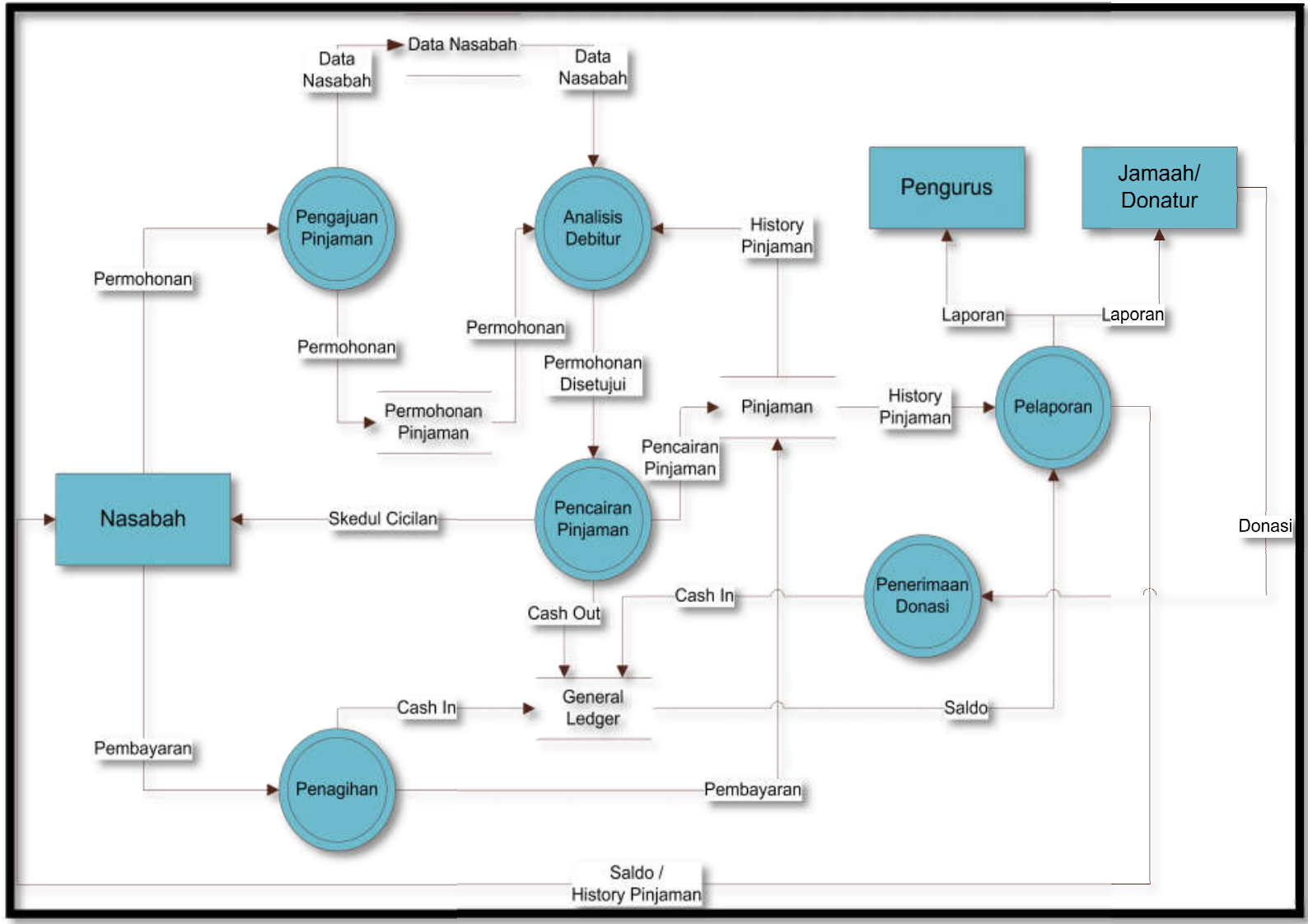

10 Jurnal Akuntansi \& Manajemen Vol 10 No.1Juni 2015. ISSN 1858-3687 hal 1-12 
Lampiran 3

Rancangan Input Pencairan Pinjaman

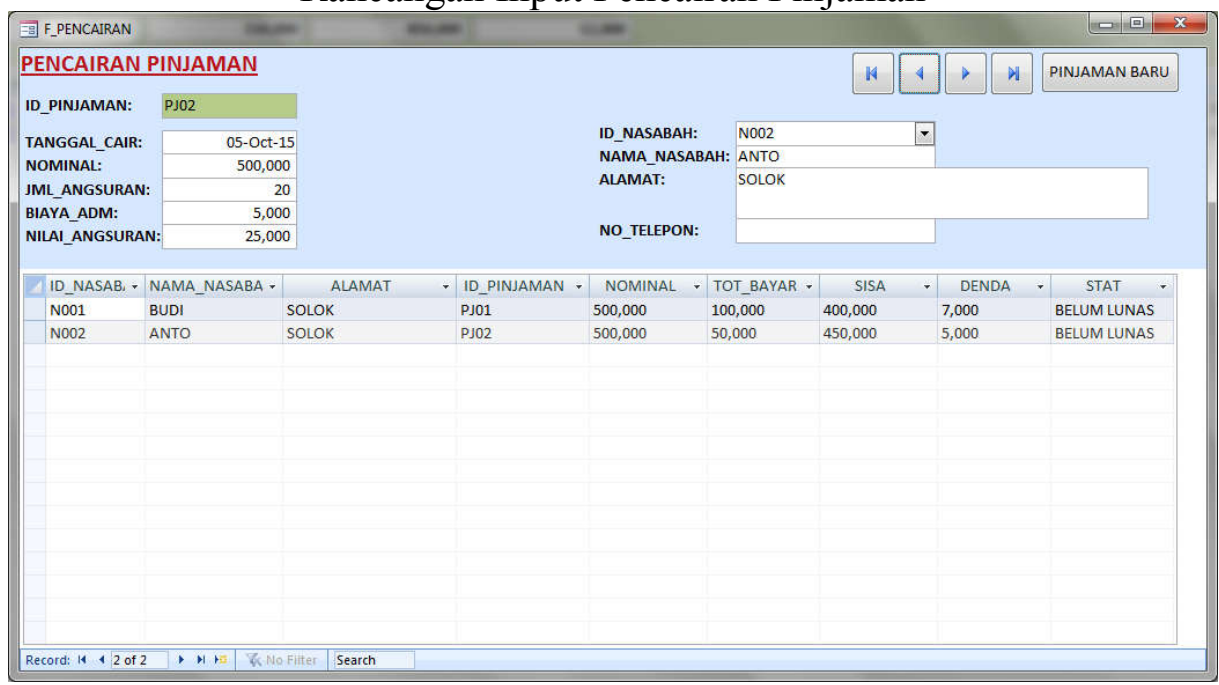

\section{Lampiran 4}

Rancangan Input Pembayaran Cicilan Pinjaman

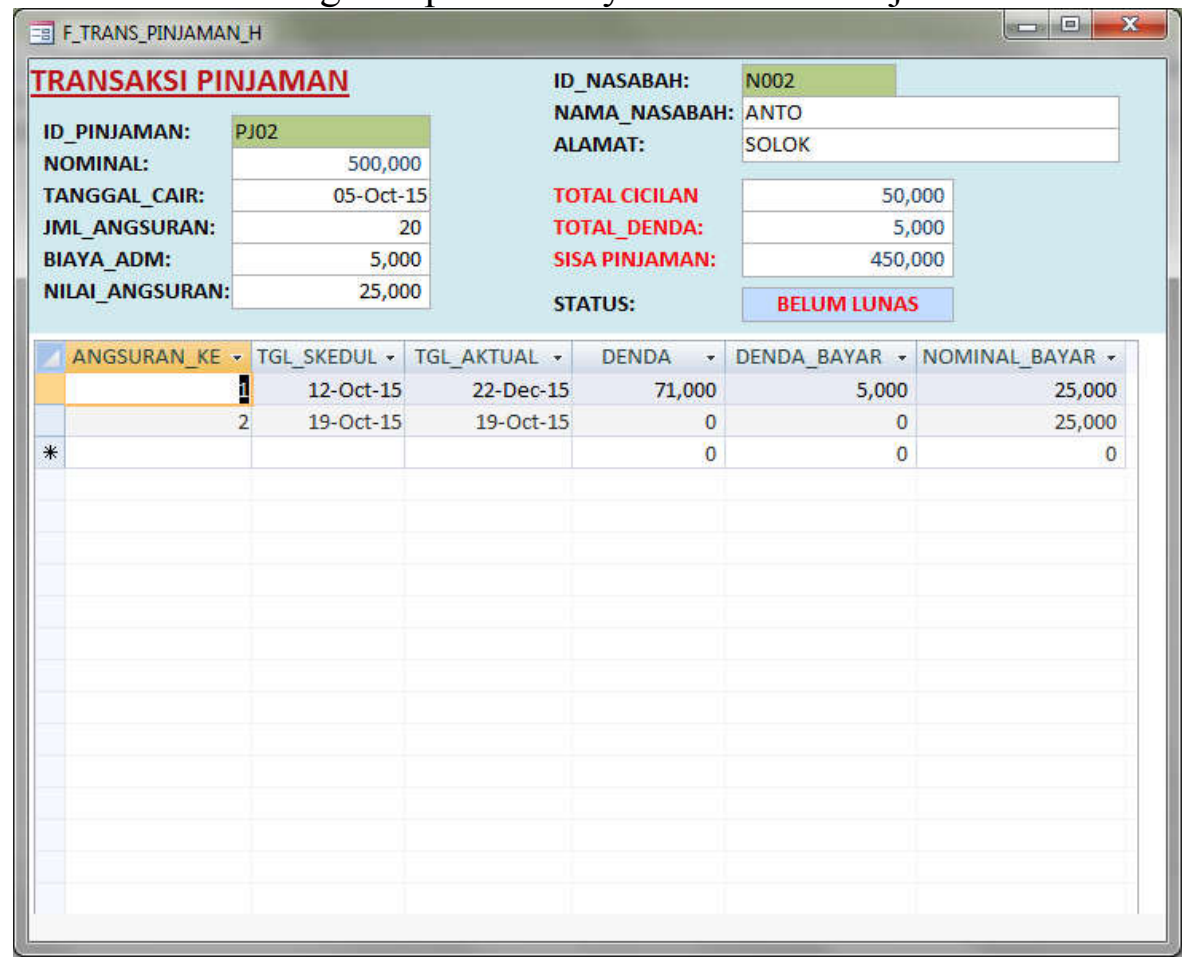


Lampiran 5

Rancangan Laporan Daftar Pinjaman

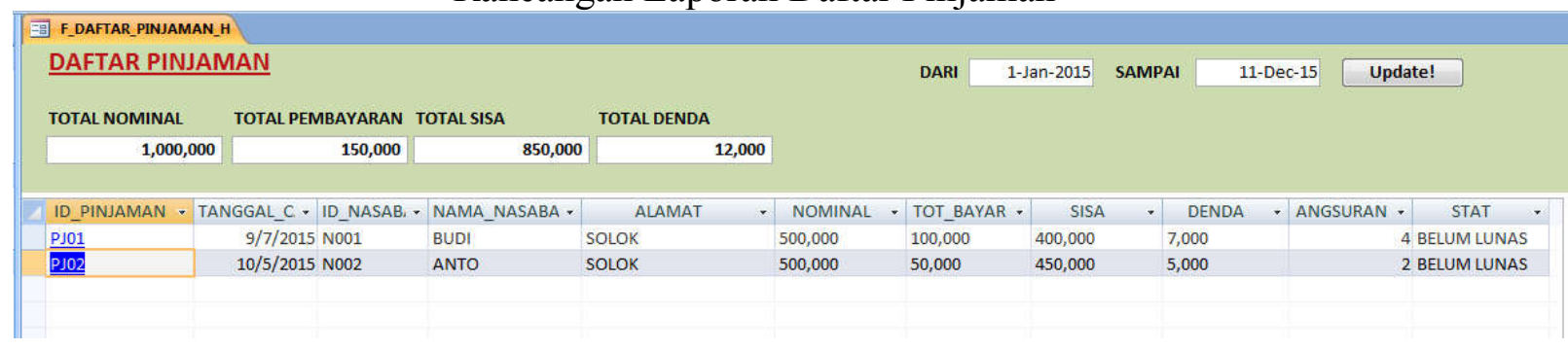

Lampiran 6

Rancangan Database Relasional

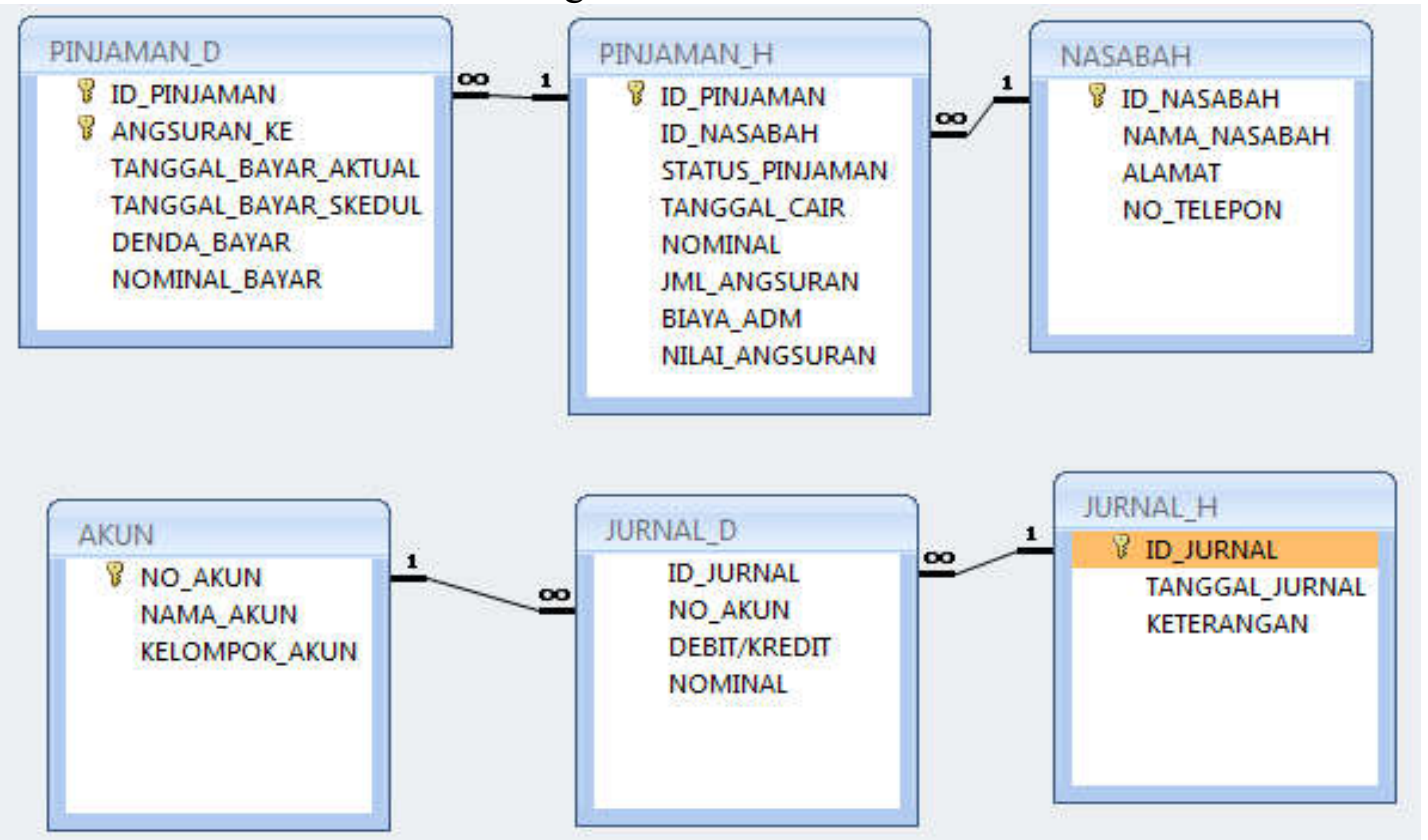

12 Jurnal Akuntansi \& Manajemen Vol 10 No.1Juni 2015. ISSN 1858-3687 hal 1-12 